\title{
A Survey of Strawberry Production Practices in Virginia
}

Authored by John Christman III, Research Intern, Hampton Roads Agricultural Research and Extension Center, School of Plant and Environmental Sciences; and Jayesh B. Samtani, Assistant Professor and Small Fruit Extension Specialist, Hampton Roads Agricultural Research and Extension Center, School of Plant and Environmental Sciences

\section{Introduction}

About 85 commercial strawberry growers operate in the Commonwealth of Virginia (Gail Milteer, Virginia Department of Agriculture and Consumer Services, Sales and Market Development, personal communication, [May, 2019). In recent years, there has been very little documentation of current strawberry production practices followed by growers in the Commonwealth. In 2016, Virginia Cooperative Extension (VCE) conducted an in-class needs assessment survey at three strawberry grower meetings in Virginia using an interactive polling software system (Turning Technologies, Youngstown, Ohio). To our knowledge, this is the first survey conducted to assess strawberry production practices of commercial growers in the Commonwealth of Virginia. The objective of the survey was to ascertain certain strawberry production practices in Virginia and to determine grower needs for research and outreach.

The meetings were held in Charlottesville, Richmond, and Virginia Beach. Virginia growers attending the meetings represented 43 commercial strawberry farms from across the state. Participation in the survey was voluntary. In total, 30 commercial growers participated in the survey with each grower representing an individual strawberry production farm. A few growers attended meetings at more than one location, but they were permitted to participate only once in the survey. Out-of-state growers were not allowed to participate in the survey. The questions were set up as multiple choice and are listed in the appendix. Grower responses to the survey remained anonymous, and the responses could not be traced back to individual growers. Not all questions were answered by all participating growers, but every question had 27 or more responses. Findings from the survey are presented and discussed below.

\section{Crop Acreage and Land Management}

Respondents were asked how they manage their strawberry crop in terms of acreage, fumigation, and crop rotation. Figure 1 shows the amount of land these growers use for strawberry production at their farms. Of those surveyed, $25 \%(\mathrm{n}=7)$ grow strawberries on less than one acre of land, while the majority, $43 \%$ $(\mathrm{n}=12)$ grow strawberries on 1 to 3 acres.

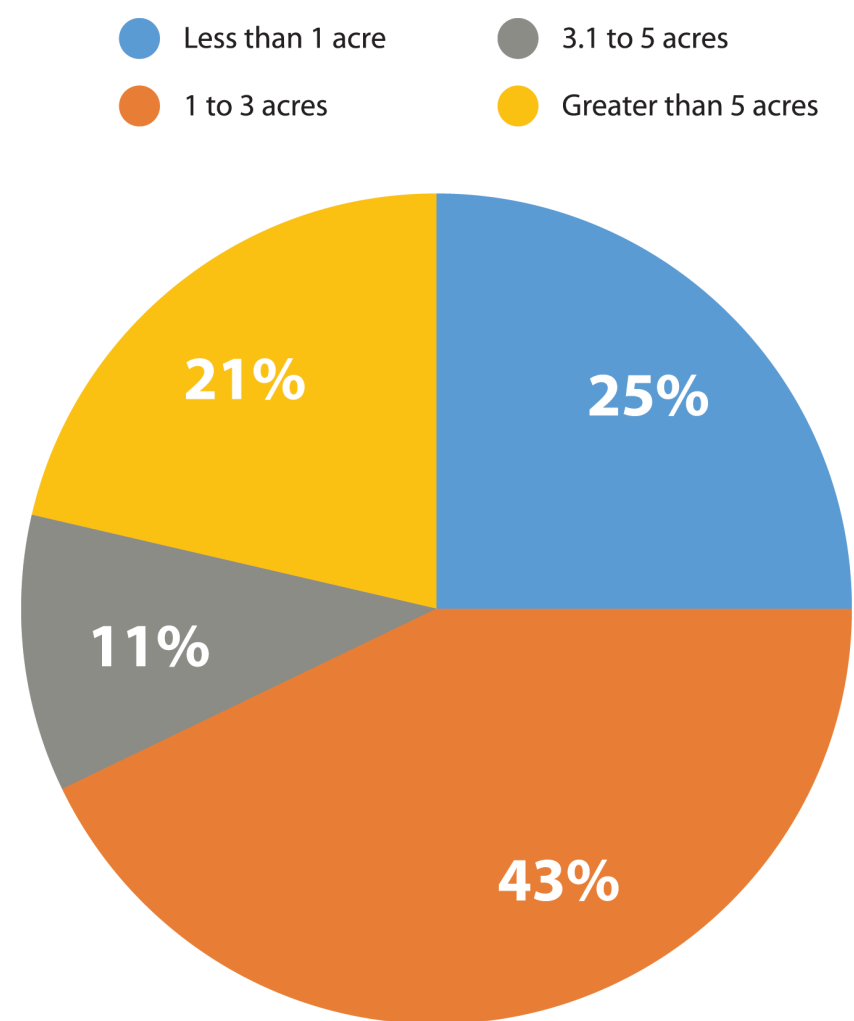

Figure 1: Strawberry field sizes in Virginia. 
These findings were as expected based on observations of strawberry farms one of the authors has visited over the past few years and from communication with Virginia Cooperative Extension agents.

Regarding fumigation practices, $50 \%$ of respondents stated that they do not fumigate before planting strawberries, while the other $50 \%$ do. Of those who do fumigate $(n=14), 21 \%(n=3)$ don't do it every year. Although it was not possible to separate the responses of growers based on farm size (due to the anonymity of the survey), most large farms are likely to fumigate their soil annually to reduce the risk of soil-borne diseases. Growers who fumigate do so because they see benefits of this practice in reduced disease and weed pressure during the growing season and possibly in improved yields. Some growers fumigate to reduce financial risks associated with strawberry production. Growers who do not fumigate likely have many reasons for not doing so, including lack of technical know-how, personal philosophy toward farming, a need to maintain buffer zones surrounding fumigated land, or issues presented by other regulations that come with the application of fumigation. Some growers indicate that they do not see the economic benefit of soil fumigation.

To assist with this decision process, VCE encourages growers to assess the pest pressure in their field in the past and current season, be sure they understand the pest life cycle, and then determine whether fumigation would be beneficial for their fields. Extension also encourages growers to pay attention to the strengths and weaknesses of each soil fumigant option available. The Southeast Regional Strawberry Integrated Pest Management (IPM) Guide, available online at http:// www.smallfruits.org/assets/documents/ipm-guides/ StrawberryIPMGuide.pdf, provides a good overview of fumigant options and their relative efficacy on various types of pests. VCE encourages growers to think about including preplant herbicides if weeds are troublesome at their farm sites. Information on available herbicides, their respective dose rates, and plant-back restrictions is available in the IPM guide.

When growers were asked about whether or not they rotate their strawberry cropland, $66 \%$ of growers $(n=18)$ responded they do, but of those growers, $22 \%$ $(n=4)$ only do so in certain years. Crop rotation has numerous benefits including breaking pest cycles, increasing soil microbial diversity, and improving nutrient availability. The greatest benefit is seen when the strawberry crop is planted on the same piece of land only every three to five years (McWhirt, Fernandez and Schroeder-Moreno 2014). However, due to practical considerations, such as availability and position of irrigation lines and roadside access to attract customer traffic and customer ease of access to the farms, many growers use the same piece of land to produce strawberries for many years without rotation. For growers who do not rotate, practices such as summer cover cropping and composting is valuable. Summer cover crops to consider include legumes, such as cowpea and soybean, and grasses, including buckwheat and pearl millet (McWhirt, Fernandez and Schroeder-Moreno 2014). For annual hill plasticulture production, sorghum-sudangrass should be avoided as a summer cover crop because the stalks can get too thick if left to mature in the field and thus take longer to decompose once mowed and incorporated in the soil. These stalks then get in the way of the bed formation process, resulting in puncturing of the plastic at the time of bed-making and leaving excessive air space in the soil of raised beds.

\section{Production Practices}

All but one of the 27 respondents (96\%) use conventional methods of production. Two additional growers plan on becoming organic growers in the coming years. These findings are not surprising considering the challenges of growing strawberries in an organic system, particularly for strawberry production on the East Coast of the United States, where the atmospheric humidity and temperature levels are high in the spring and summer. The hot and humid climate in the flower and fruiting season can promote the development of anthracnose (Colletotrichum spp.) and other diseases. Lack of adequate control measures for weeds is also a challenge in organic production systems.

The annual hill plasticulture system, or AHP (fig.2), is the most common production system, used by $93 \%$ of responding growers $(n=27)$.

\section{Virginia Cooperative Extension}

www.ext.vt.edu 


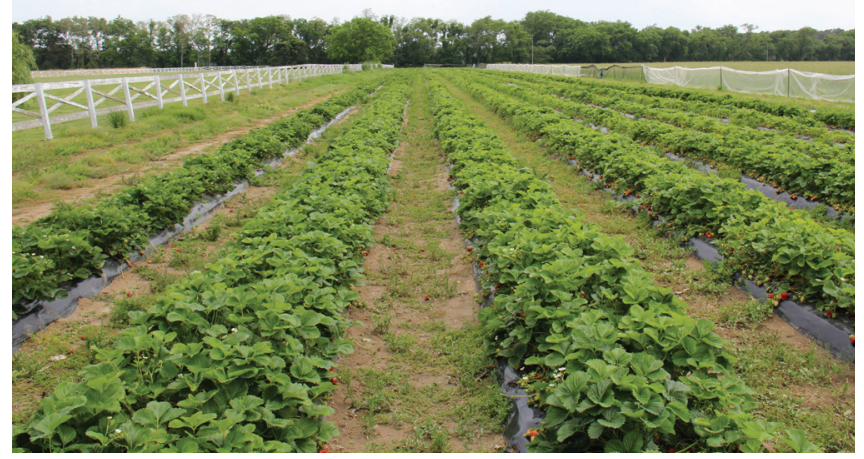

Figure 2: Strawberry crop grown in an annual hill plasticulture system. (Photo: J.B. Samtani).

These findings are not surprising as many growers in our region have transitioned from a matted-row production system to an AHP system in the past few decades. The AHP system improves fruit yield and size, improves labor efficiency for harvest, provides easier access for you-pick consumers, improves food safety practices as the fruit is not in direct contact with the soil, and eases management of soil-borne pests.

Twenty-seven percent $(n=7)$ of the surveyed growers use AHP but carry over plants in the plasticulture system. This practice is something VCE does not recommend, particularly for 'Chandler' due to the high risk of carrying over anthracnose crown rot (Colletotrichum gloeosporioides) and fruit rot $(C$. acutatum) in second-year beds, as well as increased weed pressure in the planting holes (Poling 2012).

Two growers in the survey use the matted-row production method; one of them uses matted-row exclusively, and the other uses plasticulture for matted-row production.

Growers were also asked if they perform leaf tissue analysis in the spring to assist with spring fertigation needs for the plants. More than half (55\%) stated that they do not do tissue analysis. VCE recommends doing a predictive sampling of leaf tissue and petiole analysis twice over the bloom and fruit period - once in the spring and once in early summer - for the June-bearing varieties. Specific guidelines on how to collect leaf tissue and petiole samples for strawberry are provided on the North Carolina Department of Agriculture website, http://www.ncagr.gov/agronomi/ Tissue/sberry.htm. A leaf tissue analysis allows the grower to make changes in fertigation practices and provide additional nutrients, such as boron, for improved fruit quality and yield.

\section{Strawberry Pests}

Strawberry growers must control weeds, diseases, insects, nematodes, and viruses. Growers were asked which of these pests poses the greatest threat to their crop.

Figure 3 shows that $38 \%(n=10)$ of growers responded that diseases are the greatest threat, while $31 \%(n=9)$ said weeds pose the greatest threat. None of the respondents indicated that nematodes or viruses were specifically the greatest threat, but $27 \%$ indicated that their strawberry crop is threatened by all of the pests listed. Commonly found pests for the region and their control recommendations can be found in the IPM guide.
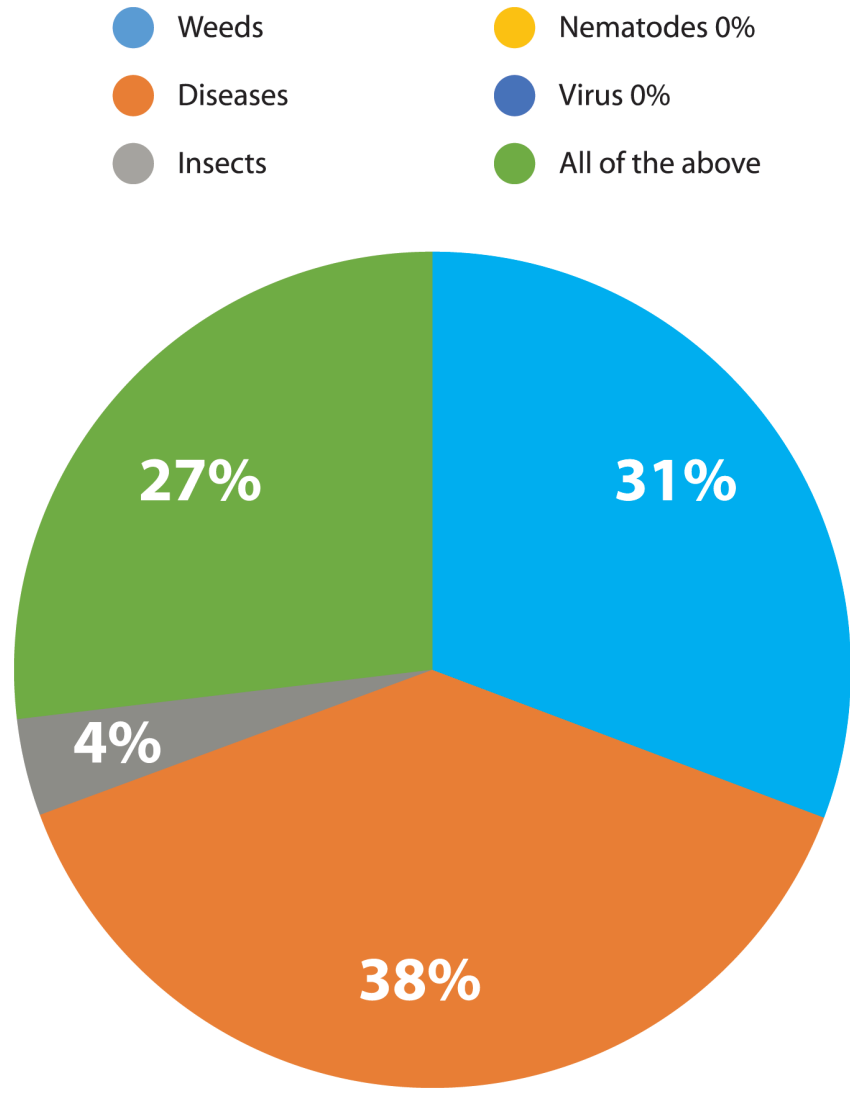

Figure 3: Strawberry growers' perceptions of what poses the greatest threat to their crop. 


\section{Strawberry Varieties}

Although a number of strawberry varieties are available, most growers in the last two decades have relied on the June-bearing varieties 'Chandler' or 'Camarosa' to meet their production needs. Additional information on these varieties is available from North Carolina State Extension at https://strawberries.ces. ncsu.edu/strawberries-plasticulture-considerationsvarieties/. As shown in Figure 4, 27\% of the respondents $(\mathrm{n}=8)$ indicated that they grow 'Chandler' exclusively and another $20 \%$ of growers stated that they grow 'Chandler' and 'Camarosa'. The other 53\% reported growing other varieties.

Only Chandler

Only Chandler and Camarosa

Other varieties

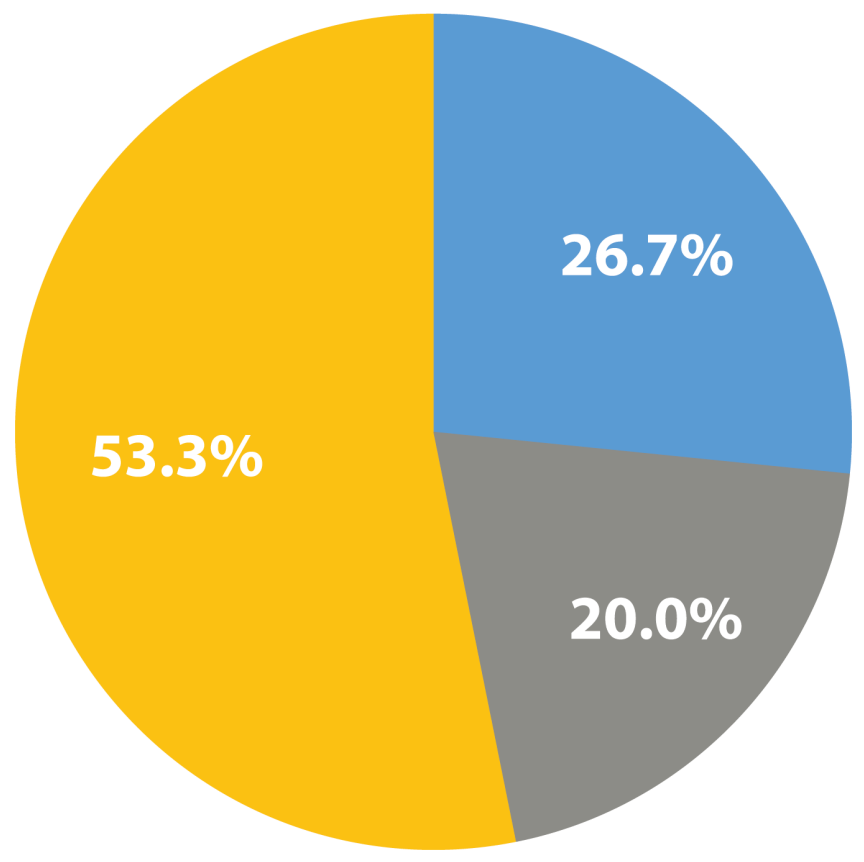

Figure 4: Strawberry varieties grown by survey respondents.

Another variety, 'Camino Real', showed promise in the strawberry trials we did at grower farms in the 2013-14 growing season. Three growers (11\%) said they will adopt 'Camino Real' on their farms. Another 26\% said they are open to it but are waiting to see more evaluation data on the variety. Our data so far indicates that 'Camino Real' is a fairly high- yielding variety with yields comparable to 'Chandler' and has the ability to withstand rain much better than 'Chandler'. 'Camino Real' has a different flavor than 'Chandler'.

\section{Markets}

Of the surveyed growers, $79 \%(\mathrm{n}=22)$ sell their berries through a combination of pre-pick and youpick approaches. Of the remaining growers, $14 \%$ $(n=4)$ operate as exclusively pre-pick farms and $7 \%$ $(\mathrm{n}=2)$ operate as exclusively you-pick farms (fig. 5). For those relying on you-pick activity only, our recommendation is to hire additional labor or request help of family members to pick additional berries that customers leave unpicked. These fruits would include healthy marketable fruits as well as the nonmarketable, diseased, and rotten fruits. If nonmarketable fruits are left unpicked they will likely increase disease pressure in fields as the fruiting season progresses, despite the grower keeping up with fungicide sprays. Unpicked fruits also promote fruit rot and an unpleasant odor on the farm for you-pick customers.

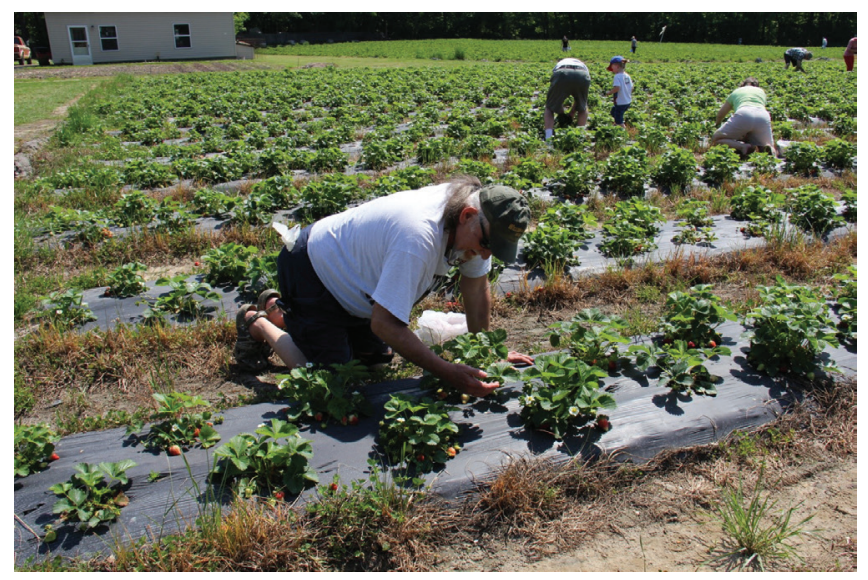

Figure 5: You-pick activity at a strawberry farm. (Photo: J.B. Samtani).

\section{Outreach and Research}

When it comes to VCE outreach methods, $61 \%$ of surveyed growers $(n=17)$ prefer field days, while $14 \%$ prefer in-class presentations (figure 6). The leastpreferred method is blogging at $3 \%$. 
Field days

YouTube videos

Fact sheets and publications

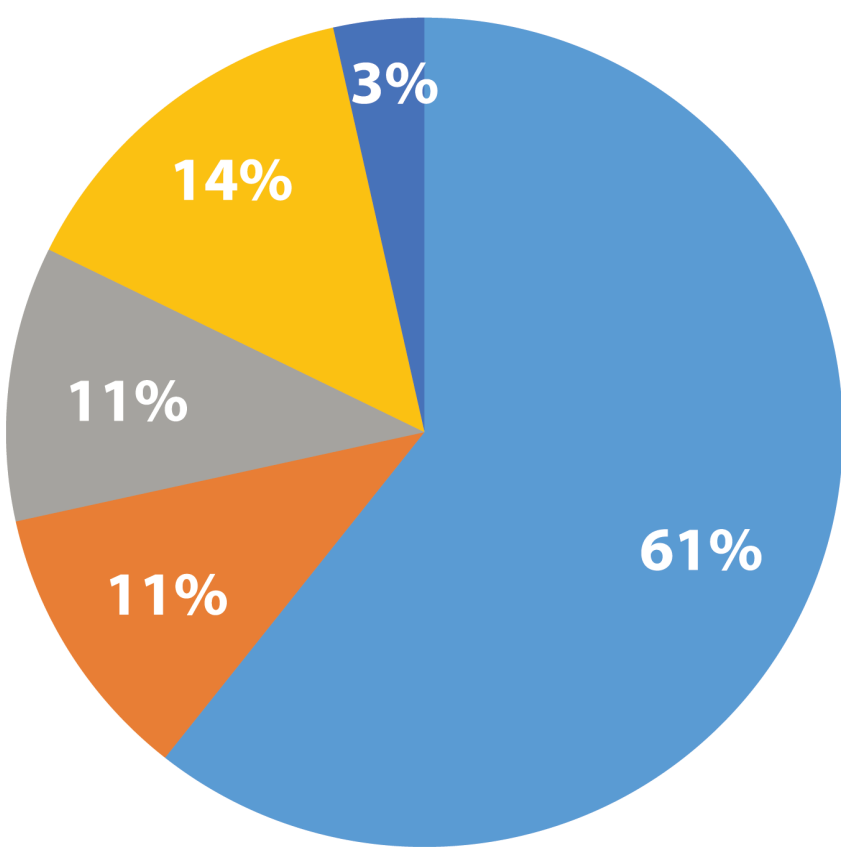

Figure 6: Preferred methods for the dissemination of information as indicated by growers.

When asked about specific research needs, $14 \%$ of the surveyed growers $(\mathrm{n}=4)$ chose "alternatives to fumigation," and 10\% each chose "plant nutrition" and "evaluation of new varieties." Most growers (66\%) stated that they wanted small fruit specialists to focus on all three issues collectively.

Based on the outcome of the survey, VCE has initiated a field day during strawberry harvest season and also worked with the Virginia Strawberry Growers Association to host post-plant field walks that are now held each year in November. The research needs identified by the grower survey has helped the Extension specialist develop a five-year research plan and implement an outreach program that includes fumigant alternatives, plant nutrition, and evaluation of new varieties.

\section{Survey Limitations}

Although there was scope to ask additional questions, the survey was limited to five minutes to retain grower participation. The survey did not go into additional details such as specific fumigants used by growers, or specific weeds or diseases of concern, nor did the authors choose to ask open-ended questions. It is possible that survey findings could have been altered slightly if there was room for open-ended questions. The anonymous setup of the survey did not allow us to correlate responses to the questions such as fumigation practice, tissue sampling, etc. by specific farm acreage. Nonetheless, this survey provides a broad overview of the current practices followed by the strawberry growers in the Commonwealth of Virginia and the directions to pursue in strawberry research and outreach.

\section{Appendix: Survey questions and multiple-choice answers}

\section{Crop acreage and land management}

1. How many acres of strawberry are you growing?

Less than 1 acre

1 to 3 acres

3.1 to 5 acres

Greater than five acres

2. Do you fumigate prior to planting berries?

Yes, always

No

Yes, but not every year

3. Do you rotate your strawberries?

Yes

No

Only in certain years

\section{Production practices}

4. Are you an organic grower?

Yes

No 
5. If no, do you plan to grow berries organically in the coming years?

\section{Yes}

No

6. What method of production are you following?

Annual hill plasticulture

Matted Row

Both

Annual hill plasticulture, but carry over plants

7. Do you do plant tissue analysis each spring?

Yes

No

8. In a normal year, what pests are of the greatest threat to your plants?

Weeds

Diseases

Insects

Nematodes

Virus

All of the above

9. What variety do you grow?

'Chandler'

'Camarosa'

Only 'Chandler' and 'Camarosa'

Other varieties

10. Are you going to try 'Camino Real' this coming year?

Yes

No

Will wait to see more evaluation data

\section{Marketing}

11. How do you sell your strawberries?

Pre-pick

You-pick

Both pre-pick and you-pick

\section{Research and outreach}

12. What Virginia Extension outreach method do you prefer?

Field days

Fact sheets and publications

YouTube videos

In-class presentations

Blogs

13. What areas would you like your small fruit specialists to focus on?

Alternatives to fumigation

Plant nutrition

Evaluation of new varieties

All of the above

\section{References}

McWhirt, A., G. Fernandez, and M. Schroeder-

Moreno. 2014. Sustainable Practices for Plasticulture Strawberry Production in the Southeast. AG-796. North Carolina State Extension. https://content.ces.ncsu.edu/sustainablepractices-for-plasticulture-strawberry-productionin-the-southeast

Poling, B. 2012. Strawberry Plasticulture Notebook: A Guide to Strawberry Plasticulture Production. The North Carolina Strawberry Association

\section{Acknowledgements}

Thanks to Mark Hoffmann, Toktam Taghavi, Roy Flanagan III and Taylor Clarke for reviewing this publication. 